\title{
Biosemiotics and the problem of intrinsic value of nature
}

\author{
Kalevi Kull \\ Department of Semiotics, University of Tartu \\ Tiigi St. 78, 50410 Tartu, Estonia \\ e-mail: kalevi@zbi.ee
}

\begin{abstract}
This article poses the hypothesis that the problem of the intrinsic value of nature that stems from the work of G. E. Moore and is widely discussed in environmental philosophy, has a parallel in a contemporary discussion in semiotics on the existence of semiosis in nature. From a semiotic point of view, value can be defined as an intentional dimension of sign. This is concordant with a biological interpretation of value that relates to biological needs. Thus, a semiotic approach in biology may provide a useful tool for further analysis of the intrinsic value problem in the biological realm. From an ecosemiotic point of view, the problem is also related to the concepts of bioart and ecoart. Ecoart viz environmental art is that which encompasses the human ambience, e.g., landscape or its components. Bioart can be defined as the art whose material ("clay") is a living body, living matter or communication of organisms (which may include, e.g., genetic engineering). It is concluded that the acceptance of biosemiotic view has implications for a large area of ecological philosophy.
\end{abstract}

It is remarkable to notice how three very different areas of naturerelated studies are intertwined in contemporary semiotics:

(a) discussion on the semiotic threshold (protosemiotics),

(b) research on semiosic communication of non-human organisms (biosemiotics),

(c) analysis of cultural representations of nature (ecosemiotics).

The biological turn in semiotics, which was initiated by the work of T. A. Sebeok $(1976,1987)$, incorporates these three areas. The demonstration of sign communication in and among non-conscious organisms logically implies the conclusion about the lowering of 
semiotic threshold. The latter creates a possibility to view nature in terms unusual for the large part of recent natural-scientific biology, and also for contemporary culture, which has learned from science ways to deal with nature. Therefore, semiotic biology - as developed along Sebeok's tradition - can be viewed as central for the other areas - for the threshold problem, and for ecosemiotic studies.

Parallel to these developments in semiotic research, the cultural applications of ecology and the environmental or ecological turns in philosophy show similar tendencies, although environmental philosophy, despite its very diverse methodology, usually applies simple biological ideas and rarely embraces the more profound results of theoretical biology.

Thus, the development of biosemiotics - as related to fundamental problems of both semiotics and biology - may directly influence the entire realm of questions listed above, and accordingly may become a central source for environmental philosophy.

In this paper, without going into the depths of the value concept, I attempt to give a brief comparison between some uses of one of the central concepts that may well provide a bridge between biology and its cultural applications.

\section{The hypothesis: biological turn in semiotics and ecological turn in philosophy are related}

The concept of intrinsic value of nature as formulated, e.g., by G. E. Moore and widely discussed in the fields of deep ecology, ethics of nature and environmental philosophy, concerns the applicability of the notion of value for non-human systems (for a review, see Vilkka 1997). Traditionally, these discussions (e.g., Callicott 1989, Norton 2000, Rolston III 2000, Zimmerman 1988) are in no way related to semiotics, rather they stem from the writings of Aldo Leopold (1989) and a few other early ecophilosophers. The central topic in these works concerns the origins of the natural values and the applicability of the concept of value to non-humans, either to other animals, or to all living beings, or to ecosystems, or even to all of nature.

Although not directly related, this can be seen as at the very least analogous to another discussion in biosemiotics that addresses the problems of the origin of semiosis and the applicability of the notion of sign in non-human living world. The discussion on the existence of 
the intrinsic value is to a large extent parallel to the discussion on the placement of semiotic threshold. In both cases, i.e. for concepts of value and of sign, the initially anthropomorphic terms are applied to animals and extended to all other living beings.

I raise the hypothesis that the apparent parallelism between the problem of intrinsic value of nature in environmental philosophy and the whole set of questions on biosemiosis are intimately related and therefore, some results of biosemiotic analysis may be applicable to the analysis of the intrinsic value problem.

The entire problem of the origin of sign can be treated in the scope of theoretical biology, or as of a branch of it, biosemiotics (Emmeche 1992). Thus, in addition, we may also ask whether, in a similar way, the concept of value and the problem of the origin of value can be seen as a problem of theoretical biology and biosemiotics.

Thus, the statement is that the problem of intrinsic value of nature, which may primarily be attributed to ecosemiotics because it concerns cultural views on nature (Kull 1998), can be seen from the point of view of biosemiotics, i.e., as dealing with the sign processes in living nature. This will be the point of departure of this study. We may also hypothesise that the concept of intrinsic value of living systems may coincide with any of already existing concepts in biology or biosemiotics.

\section{The concept of intrinsic value of nature in environmental philosophy}

For a great part of contemporary environmental philosophy, the basic problem converges in the acceptance and interpretation of the intrinsic value of nature. For instance, the Deep Ecology Platform as formulated in eight basic principles starts with the claim on that:

The well-being and flourishing of human and non-human life on Earth have value in themselves (synonyms: intrinsic value, inherent worth). These values are independent of the usefulness of the non-human world for human purposes. (Naess 1993: 197).

Naess gives the following comment on this point:

This formulation refers to the biosphere, or more professonally, to the ecosphere as a whole (this is also referred to as 'ecocentrism'). This includes individuals, species, populations, habitat, as well as human and non-human 
cultures. Given our current knowledge of all-pervasive intimate relationships, this implies a fundamental concern and respect.

The term 'life' is used here in a more comprehensive non-technical way also to refer to what biologists classify as 'non-living': rivers (watersheds), landscapes, ecosystems. For supporters of deep ecology, slogans such as 'let rivers live' illustrate this broader useage so common in many cultures. (Naess 1993: 197-198)

In this regard, Holmes Rolston III (2000) speaks of the environmental turn in ethics. Despite the wide acceptance of the intrinsic value concept and the understanding of its important implications for law, medicine, arts, etc., its limits and biological foundations remain unclear.

O'Neill (1992: 119-120) distinguishes between three different basic meanings of the term: (a) intrinsic value is used as a synonym for non-instrumental value; (b) intrinsic value is used to refer to the value an object has in virtue of its 'intrinsic properties'; (c) intrinsic value is used as a synonym for 'objective value'.

Weston (1996) proposes a pragmatist critique of the notion. He shows that intrinsic values are also operational, although in a more esoteric manner, implying that intrinsic value defined as independent and self-sufficient, may still be possible to interpret as not completely isolated from an appraiser, or a valuing subject. In this respect Callicott (1989) says that 'value' is a verb, not a noun (cf. Norton 2000: 1037-1038).

A considerable part of interpretations of the intrinsic value concept concerns the necessary turn to a biocentric view (Vilkka 1995), as opposed to the anthropocentric view. This may mean that the valuing process is extended so that the experiential world of any living being is included. However, likewise the pansemiotic version of approach in semiotics, there also exists an approach in the analysis of intrinsic value that assigns it to all nature, including the abiotic portion (Zimmerman 1988).

\section{Three ways of defining 'value' in biology}

Biology maintains several versions of value. Among these, three main types of approaches can be distinguished. Depending on context, these can be interpreted as either alternative views or different subtypes of the same concept. 
(1) Reproductive value - the notion of value as something that measures reproductive success. Reproductive success is usually characterised quantitatively via fitness measures, which is a complement of natural selection.

(2) Meronomic value - value stemming from functional differentiation. This means that a part (e.g., of an organism) always requires an additional part. Each natural part obtains its value with respect to its relationship to other natural parts.

(3) Functional value - value related to or stemming from biological needs. Valuable for an organism is what is functionally required or necessary. Needs and values mutually define one another.

Meronomic value can be called also a differential value. However, considering the use of this term in economics since the work of William Stanley Jevons, it is quantitatively expressed more analogically to the reproductive value in biology (see also Sharov 2001), on the other hand still meaning that the problem of value is that of the mind.

These three types are not entirely independent, because all are related to the concept (and possibly, a mechanism) of biological adaptation. While the reproductive value is responsible for evolutionary adaptation, the meronomic value is basically ontogenetic, and the functional value can be viewed as that upon which all organismic behaviour is based.

Integration of these three types of value is thus equivalent to finding an integral definition for the concept of adaptation. This is evidently impossible when confined to the framework of the measure of evolutionary fitness. Moreover, emphasis on biological needs results in the exclusion of some of the reproductive value phenomena, because not all differences in reproduction result from the differences in the active behaviour of organisms.

Perhaps the only integration of these concepts in the contemporary biological literature is the replacement of an organismic view by one of lineage. However, these two are associated by ontogenetic trajectory, and accordingly, if we accept that ontogeny (defined as organismic process) is a more fundamental concept than either organism or lineage, a general viewpoint can be reached that enables us to view biological values as the counterparts of generalised developmental process, including both reversible and irreversible changes. 


\section{On the concept of value in semiotics}

Value (valeur) is a technical term used by Saussure, devoting to it an entire chapter in his Cours de linguistique générale. Saussure (1983) distinguishes between the value of a sign and all its other properties. The value of a sign is determined by the network of contrasts it enters into with all other signs in the system (Harris 1998). This notion plays a key role in the whole theory of Saussurean structuralism, and sets it apart from the several later versions of structuralism. According to Saussure, the value of a term is not its 'meaning'.

According to Morris (1971: 418), a value is 'a property of an object or situation relative to an interest'. Thus, he sees in value an intentional aspect of a system.

Peirce says that analysis of meaning implies reference to a purpose (CP 5.175) and that meaning and value are intimately connected. 'Meaning is something allied in its nature to value. [...] Value is the measure of desirability; and desire always refers to the future. This leads us to inquire whether meaning does not always refer to the future' (MS 599, 1902: 24).

J. D. Johansen, when discussing the concept of value in Saussure and Hjelmslev, concludes (Johansen 1993: 50): 'the concept of value is not independent of the concept of signification; on the contrary, it depends on it'.

Reading a text, or receiving a message is always an active process. Signs are developed and distinctions drawn for that which the users find important, or which have particular significance in their Umwelt or culture.

Thus, stating that value can be defined as an intentional dimension of meaning, we will not depart far from the most of traditional usage of the term in semiotics.

\section{A biosemiotic approach}

The main types of the value concept in biology can be placed into accordance with the interpretations of value in a semiotic sense. For instance, the meronomic value as defined above is similar or possibly related to the concept of valeur of Saussure, whereas both the reproductive value and the functional value (in their biological sense) 
may have a pragmatic interpretation. However, if the reproductive value corresponds well to a strictly pragmatic interpretation of the term, then the concept of functional value can be better interpreted as being concordant with Peirce's pragmaticism.

Assuming that all values are nothing more than an intentional dimension of meaning that is counterpart to any sign, the whole problem of the existence of the intrinsic values converges into a problem of the existence of such signs in nature. According to a fundamental biosemiotic statement, semiosis starts with living cells. The intentional dimension of biosemiosis has received less attention, however, it is reasonable to assume that biosemiosis is primarily associated with the biological needs that characterise all living beings and that also represent the simplest type of intentionality. ${ }^{1}$

All biological needs seemingly stem from an organic homeostatic mechanism, although, in another formulation, any homeostatic system in organic turns out to be a pacemaker for a biological need. These have built upon themselves a hierarchy of multilevel processes (e.g., via a mechanism of metasystem transition), representing all possible forms of biological and ultimately non-biological (human) intentionality.

The developmental process of any living being, including a single cell, is either in whole or in part also an interpretant for its sign processes. Thus, as much as a living being can be independent and self-sufficient, the same can be assigned for values.

\section{An excursus to ecosemiotics: Bioart and ecoart}

Any approach to the problem of values has to be testable on aesthetic values, and the problem is whether this is also the case for intrinsic biological values. ${ }^{2}$

All organisms transform their ambience, designing paths, building nests, dramatically changing the structure, appearance or character of surface soil and subsoil by their consumption patterns and waste. Part of this designing process clearly conveys the sign function related to search and recognition.

${ }^{1}$ On the definition of biological need, see, e.g., Kull 2000.

2 Recently, some interesting work on biosemiotic interpretation of aesthetic phenomena has been carried out by A. Weber (2001) and D. Martinelli (2001). See also Corrington (1994), Ferré (1996), Jonas (1997). Concerning the relationship between biosemiotics and ethics, see also Hoffmeyer (1994, 1996). 
Environmental problems arise when a massive amount of something resisting biodegradation develops, when the impact on the environment becomes irreversible, when the system is thrown out of balance, or when something is introduced to or removed from the closed cycle of an ecosystem. These are all too familiar problems, related basically to the technical skills of humanity to employ alien, hostile-to-life materials and extra-cycle resources.

However, in addition to conflicts triggered by disturbing substance cycles, there is another major transformation of natural habitat, stemming from the overpowering drive to embellish the surroundings. This is related to the disparity between the human habitat humanity's self-created environment or home space - and the habitat of animals, even when humanity appears to practice sound ecological principles. This disparity is compounded people extending their home space to embrace all of nature.

The aesthetic aspect plays a major role in home space. It is quite natural that humanity makes recourse to all conceivable means to make his environment more appealing and interesting, particularly by conscious use of skill and creative imagination in the production of aesthetic objects.

Nature art is fairly multifaceted. Clearly distinguishable within this concept are bioart and ecoart, when defined through semiosis, through a sign process rather than through denotation - like is done in other areas of art. Hence, with art conceived as an aesthetically manipulated sign process, bioart is not regarded as drawing of butterflies and flowers, nor is ecoart tantamount to painting a landscape.

The difference may be elucidated as follows. Ecoart viz environmental art is that which encompasses our ambience - e.g. landscape or its components, soil, communities and habitats etc. Bioart would then be the art whose material ("clay") is a living body, living matter or communication of organisms (as it is, the living body can not be actually severed from the life process viz the biocommunication).

Living matter is unique in that it is itself the creator, in particular the creator of meanings unto itself. Umberto Eco, when defining the concept of semiotic threshold, placed that in the node where language starts (and culture, for that matter). The biological turn in semiotics, shifting the boundary to where life begins, heralded the understanding that awareness is not a premise of sign process, that it does not underlie it. Icons can be detected also in the ant's world, indexes with slugs, semiosphere reaching into our body, to embrace the communication between our cells. 
Supposing the semiosphere is larger, enveloping all living beings, then it must be meaningful also for art. Sign processes in living organisms are capable of creating harmony. Biology should then be partly the science of arts, education of the development of living nature being a fragment of the history of arts.

The convolution of nature art is constituted by co-operation of creators. Naturally, the inorganic matter is important for the evolution of a work of art, however the meaningfulness is the outcome of artist's craft, in the first place. Moreover, living matter is an active creator of meanings, because it entertains its own needs. Therefore, in artful transformation of the world there are certain demarcation lines where needs are concerned. This is so because needs are a vehicle for shuttling between disharmony and harmony. The needs frame the art, on the one hand, ubiquitously attending the process of vesting something with a meaning (or divesting something of the same). On the other hand, the transformation may affect the formation of the very needs - dwarfing them or inflating them irreversibly, however also eradicating them or creating new ones.

Everything alive has needs per se, not so the lifeless nor the dead. This borderline was emphasised and referred to by Albert Schweitzer. Whenever classical art changes the needs themselves, it almost exclusively affects only people - the creators and listeners-observers not other living creatures. Modern art is not shackled by this restraint. There are ample examples of cases when the needs of animals and other oxygen breathing things are modified.

The Pekingese and many other pedigree lapdogs have been bred, largely on the basis of aesthetics, likewise multicoloured fish in aquariums and supposedly many varieties of garden flowers. The most recent example to the point is a mouse, in whose genome there was transplanted a chunk of DNA of the medusa glowing in UV radiation. Whereupon the transferred gene activated in the mouse's tissues and fur, making the mouse shine like a lantern. This was just a genetically modified organism (GMO), made for an art exhibition. It can be considered as an extension of aquarium art or cultivated plants in flowerpot, "surrounded by a frame". However in that game on biological level - unlike painting, furniture and non-biological art - the art is sustainable without humanity. Once the communication in the living organism has been turned on, the organism continues to play it.

Any ostentatious mix on the level of inter-species communication represent bioart - transplanting a birch in Australia, or letting the ostrich loose on an alvar. There are unlimited aspects to games with 
biocommunication, the gene technology having ushered in a new era in that area - the art technique for combining in the sphere of endocommunication.

The best-known bioart is related to the human body, cf. body art. Make up and tattoos, and also plastic surgery - a long list of techniques capped by chemical, physiological and genetic changes, modifying behaviour.

The fundamental objection to bioart stems from the fact that a living body has at its disposal an operative harmonising process, thence its inner drive to aestheticism. Almost every interference tends to disrupt that harmony. (Healing may be regarded as an exception, but with reservations only. Suppose all pathogens and parasites should be eliminated and suppressed in wild nature - the outcome would be perilous to communities.) In this meaning, bioart is quite similar to modification of a perfect and consummate work of art. Whence the conclusion that bioart is always co-operation of at least two artists.

The concept of ecoart is characterised by the magnificence of scale, related to setting boundaries on the concept of environment (including the communication of organisms etc.). There is a wide expanse of phenomena, ranging from skin-deep to sky-high: habiliments, living room, house, garden, landscape, and correspondingly, art of fashion, interior decoration, urban architecture, art of planting trees and shrubs, landscape architecture and design.

All those are predominantly industrial arts, i.e., directly linked to human needs for living or functions of living. Therefore, unlike bioart, ecoart is indispensable. Of course, in all those areas non-industrial art is possible. Nature has a whole culture on offer, in this respect.

\section{Conclusion}

To take biosemiotics seriously implies not only a paradigmatic turn for at least some part of biology, but also infers important and interesting changes in the views of various aspects in the theory of culture and semiotics of culture. In addition, this approach may be helpful in order to comprehend some puzzles of environmental philosophy. Defining value as an intentional dimension of sign, it becomes possible to trace a line from biological needs to the cultural representations of value, approaching with this a biosemiotic interpretation of the intrinsic value of nature. 


\section{References}

Callicott, J. Baird 1989. In Defense of the Land Ethic. Albany: State University of New York Press.

Corrington, Robert S. 1994. Ecstatic Naturalism: Signs of the World. Bloomington: Indiana University Press.

Emmeche, Claus 1992. Modeling life: A note on the semiotics of emergence and computation in artificial and natural living systems. In: Sebeok, Thomas A.; Umiker-Sebeok, Jean (eds.). Biosemiotics: The Semiotic Web 1991. Berlin: Mouton de Gruyter, 77-99.

Ferré, Frederick 1996. Being and Value: Toward a Constructive Postmodern Metaphysics. Albany: State University of New York Press.

Harris, Roy 1998. Introduction to Integrational Linguistics. Oxford: Pergamon Press.

Hoffmeyer, Jesper 1993. Biosemiotics and ethics. In: Witoszek, Nina; Guldbrandsen, Elisabeth (eds.), Culture and Environment: Interdisciplinary Approaches. Oslo: Centre for Development and the Environment, 152-176.

- 1996. Signs of Meaning in the Universe. Bloomington: Indiana University Press.

Johansen, Jørgen Dines 1993. Dialogic Semiosis: An Essay on Signs and Meaning. Bloomington: Indiana University Press.

Jonas, Hans 1997 [1973]. Das Prinzip Leben: Ansätze zu einer philosophischen Biologie. Frankfurt: Suhrkamp.

Kull, Kalevi 1998. Semiotic ecology: Different natures in the semiosphere. Sign Systems Studies 26, 344-371.

- 2000. An introduction to phytosemiotics: Semiotic botany and vegetative sign systems. Sign Systems Studies 28: 326-350.

Leopold, Aldo 1989 [1949]. A Sand County Almanac and Sketches Here and There. New York: Oxford University Press.

Martinelli, Dario 2001. Methodologies and problems in zoomusicology. Sign Systems Studies 29(1): 341-352.

Morris, Charles W. 1971. Writings on the General Theory of Signs. The Hague: Mouton.

Naess, Arne 1993. The deep ecological movement: Some philosophical aspects. In: Zimmerman (ed.) 1993, 193-212.

Norton, Bryan G. 2000. Biodiversity and environmental values: In search of a universal earth ethic. Biodiversity and Conservation 9(8): 1029-1044.

Nöth, Winfried 1990. Handbook of Semiotics. Bloomington: Indiana University Press.

O'Neill, John 1992. The varieties of intrinsic value. The Monist 75(2): 119-137.

Rolston III, Holmes 2000. The land ethic at the turn of the millennium. Biodiversity and Conservation 9(8): 1045-1058.

Saussure, Ferdinand de 1983 [1916]. Course in General Linguistics. London: Duckworth.

Sebeok, Thomas A. 1976. Contributions to the Doctrine of Signs. Bloomington: Indiana University Press. 
- 1989. The Sign and its Masters. Lanham: University Press of America. Sharov, Alexei 2001. Umwelt-theory and pragmatism. Semiotica 134(1/4). Vilkka, Leena 1995. The Varieties of Intrinsic Value in Nature: A Naturistic Approach to Environmental Philosophy. Helsinki: University of Helsinki.

- 1997. The Intrinsic Value of Nature. Amsterdam: Rodopi.

Weston, Anthony 1996 [1985]. Beyond intrinsic value: Pragmatism in environmental ethics. In: Light, Andrew; Katz, Eric (eds.), Environmental Pragmatism. London: Routledge, 285-306.

Weber, Andreas 2001. Cognition as expression: On the autopoietic foundations of an aesthetic theory of nature. Sign Systems Studies 29(1): 153-168.

Zimmerman, Michael E. 1988. Quantum theory, intrinsic value, and panentheism. Environmental Ethics 10(1): 3-30.

- (ed.) 1993. Environmental Philosophy: From Animal Rights to Radical Ecology. Englewood Cliffs: Prentice Hall.

\section{Биосемиотика и проблема внутренней ценности природы}

В статье выдвигается гипотеза, что сформулированная Дж. Э. Муром и широко дискутируемая в философии окружающей среды проблема внутренней ценности природы сопоставима с дискуссией в современной семиотике о семиозисе в природе. С точки зрения семиотики ценность можно дефинировать как интенциональное измерение. Это соответствует биологической трактовке ценности, если рассматривать ее, исходя из биологических нужд. Таким образом, семиотический подход в биологии может послужить и при анализе проблемы внутренней ценности природы. В экосемиотическом аспекте это проблема связана и с био- и экоискусством. Экоискусство - это искусство, занимающееся средой человека, например пейзажем. Биоискусство можно определить как искусство, материалом которого является живое тело или коммуникация организмов (включая частично инженерную генетику). Отсюда следует, что акцептирование биосемиотической точки зрения влечет за собой множество выводов, затрагивающих и экологическую философию.

\section{Biosemiootika ja looduse sisemise väärtuse probleem}

Artiklis püstitatakse hüpotees, mille kohaselt G. E. Moore'i poolt formuleeritud ja keskkonnafilosoofias laialdaselt diskuteeritav looduse sisemise väärtuse probleem on paralleelne tänapäeva semiootikas toimuva diskussiooniga semioosise esinemisest looduses. Semiootika seisukohalt võib väärtust defineerida kui märgi intentsionaalset mõõdet. See on vastavuses väärtuse bioloogilise tõlgendusega, kui seda käsitleda lähtuvana bioloogilistest vajadustest. Seega võib semiootiline lähenemine bioloogias olla vahendiks ka 
looduse sisemise väärtuse probleemi analüüsil. Ökosemiootilisest aspektist on probleem seotud bio- ja ökokunstiga. Ökokunst on kunst mis tegeleb inimese keskkonnaga, näiteks maastikuga. Biokunsti võib määratleda kui kunsti, mille materjaliks on elus keha või organismide kommunikatsioon (haarates osalt ka insenergeneetika). Seega osutub, et biosemiootilise vaatekoha aktsepteerimisega kaasneb hulk järeldusi, mis puudutavad ka ökoloogilist filosoofiat. 